\title{
AUTOGRAPHS FOR FREEDOM AND REACHING A NEW ABOLITIONIST AUDIENCE
}

\author{
John R. McKivigan and Rebecca A. Pattillo
}

Scholars correctly appreciate Frederick Douglass's novella The Heroic Slave (1853) as an important early work of African American literature and as a significant indicator of its author's endorsement of violent tactics to end slavery in the United States. ${ }^{1}$ This essay will literally step back farther from the text of Douglass's only fictional work, and examine The Heroic Slave as a component of a larger project - the gift book Autographs for Freedom - edited by Douglass and his closest ally in the early 1850 s, British abolitionist Julia Griffiths. The thirty-nine pieces of short fiction, poetry, essays, and correspondence in the 263-page anthology were envisioned as tools to construct a wider and politically more potent antislavery alliance than any in which the two abolitionists had previously participated. In the diverse composition of its collection of authors and antislavery themes, Autographs for Freedom was both a cultural and political tool designed by Douglass and Griffiths to help assemble a more powerful antislavery coalition from the volume's reading audience.

The publication of Autographs for Freedom marked a further move by Douglass away from his original abolitionist mentors, the followers of Boston newspaper editor William Lloyd Garrison. This estrangement had been festering for nearly a decade. Since shortly after his hiring as an itinerant antislavery lecturer in 1841, Douglass had chafed at instructions from his Garrisonian employers to keep his lectures focused on recounting personal experiences from his Maryland slave life, rather than addressing complex ideological antislavery issues. Two years lecturing in Britain following the 1845 publication of his first autobiography, Narrative of the Life of Frederick Douglass, An American Slave, and the purchase of his freedom by British admirers, had produced a considerable increase in Douglass's self-confidence. ${ }^{2}$

In 1847 Douglass returned to the United States with substantial financial contributions from British sympathizers who had encouraged him to launch his own newspaper on behalf of oppressed African Americans. Garrison and his abolitionist followers initially dissuaded Douglass from commencing this journalistic venture. They feared it would draw the talented orator away from the lecture circuit and create competition for Garrison's Liberator for readers and contributions, but

Rebecca A. Pattillo is Archive Collections Manager at the Carmel Clay Historical Society, Indianapolis, IN. 
Douglass maintained his desire to demonstrate the capacity of an African American to conduct such an enterprise. ${ }^{3}$

\section{LAUNCHING THE NORTH STAR}

The selection of Rochester in western New York as the site to publish the North Star appears to have been a calculated maneuver by Douglass to get outside the Garrisonian orbit. The move brought Douglass into closer contact with abolitionists of other ideological and tactical inclinations. For example, he interacted with religious abolitionists who differed from the Garrisonians in their vision of American churches becoming effective antislavery instruments. More significantly, Douglass found support from political antislavery circles, both adherents of the Liberty Party and more moderate opponents of slavery's westward expansion. Douglass also took the opportunity his prominence as an editor gave him to play a leading role in the free black community in northern states. ${ }^{4}$

The inaugural issue of the North Star appeared on 3 December 1847, but by spring of the next year the paper had deep financial troubles. Douglass wrote to his British friend Julia Griffiths in April 1848, "The North Star must [be] sustained. It has [already] accomplished [something]. It has taken a respectable stand among (at least) American newspapers - and in a measure demonstrated the slaves' capacity for higher achievements. It has also impressed the colored people themselves, that they are destined [for] higher attainments - even in this country than [they] now enjoy." "Griffiths wasted no time and by May 1849 had settled in Rochester to help ensure that Douglass's paper received sufficient financial support from subscribers and benefactors. Griffiths became the newspaper's editorial assistant, but more importantly, she reorganized the North Star's financial and office management, and helped expand its subscriber list, especially among British abolitionists. A firm evangelical, Griffiths roused the suspicions of Garrisonians about encouraging Douglass to break with his Boston friends. They launched a rumor campaign, which quickly became public, that Griffiths and Douglass were engaged in a romantic, even sexual, relationship that was producing serious tensions inside Douglass's household. ${ }^{6}$ 


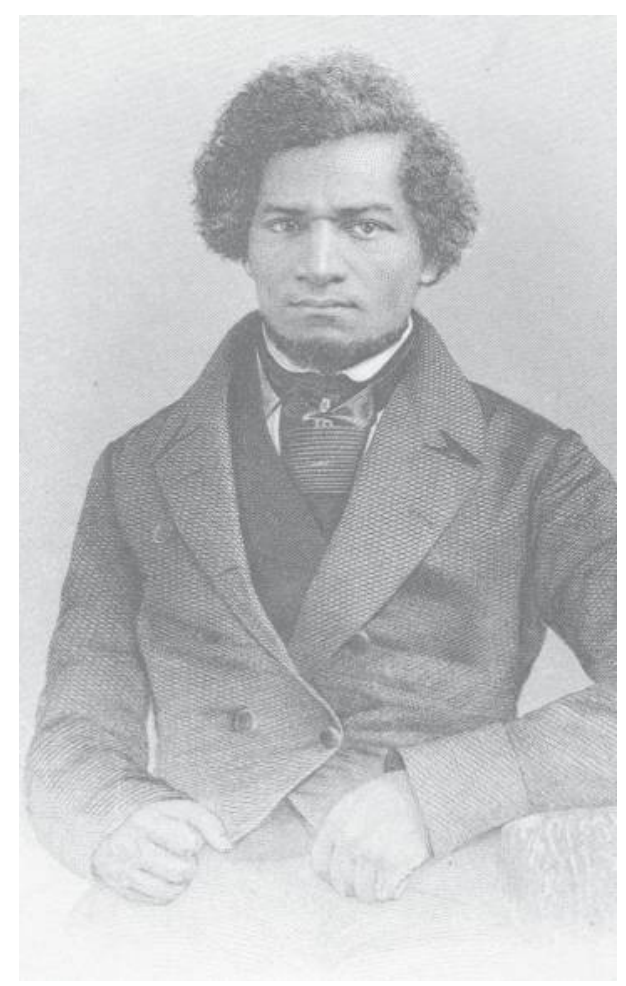

Frederick Douglass (in the 1850s)

Locally, Griffiths helped revive the Rochester Ladies' Anti-Slavery Sewing Circle, later renamed the Rochester Ladies' Anti-Slavery Society (RLASS). To raise funds for Douglass's newspaper, Griffiths guided her female compatriots in organizing a series of festivals and lectures. ${ }^{7}$ She also launched plans for a holiday gift book to sell with proceeds going to the North Star. By the 1850s gift books such as Autographs for Freedom were part of a growing tradition in transatlantic reform circles. Often elaborately bound and sold as gifts during the holiday season, 


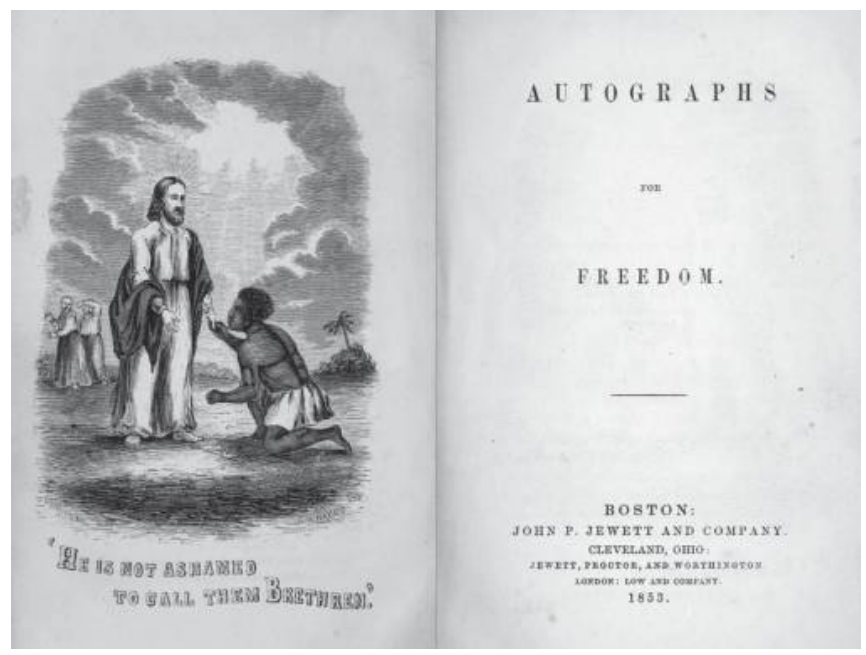

Autographs for Freedom Title Page

these anthologies combined literary pieces such as poetry and short stories, essays, speech excerpts, and sometimes engravings or other forms of art. Gift books started in Great Britain as a commercial enterprise and were popular courtship gifts. The gift book was adopted for reform causes by American abolitionists such as Lydia Maria Child, who edited The Oasis (1834), and John Greenleaf Whittier, who edited the North Star (1840). The Liberty Bell, edited by close Garrison associate Maria Weston Chapman to benefit the American Anti-Slavery Society, first appeared in 1839, and ultimately had fifteen volumes before being discontinued in $1858 .^{8}$ Douglass himself had written pieces for two Liberty Bell issues before his break with its Garrisonian sponsors.

The Heroic Slave and the other contributions in the 1853 edition Autographs for Freedom appeared at a time when Douglass was rapidly pulling away from his original Garrisonian antislavery supporters, but their replacement was as yet unclear. Ever the tactical pragmatists, Douglass and Griffiths sought in the diverse positions advanced by the writers they recruited for the gift book to assemble a new and broader antislavery coalition than Garrison's. The eclectic political and literary pieces they published represented several distinct departures from the ideological positions of the Garrisonians. Furthermore, the Rochester Ladies' AntiSlavery Society claimed no official political affiliation, allowing them to reach out to a wide range of political, religious, and African American abolitionists for their volume's collection. ${ }^{9}$ 


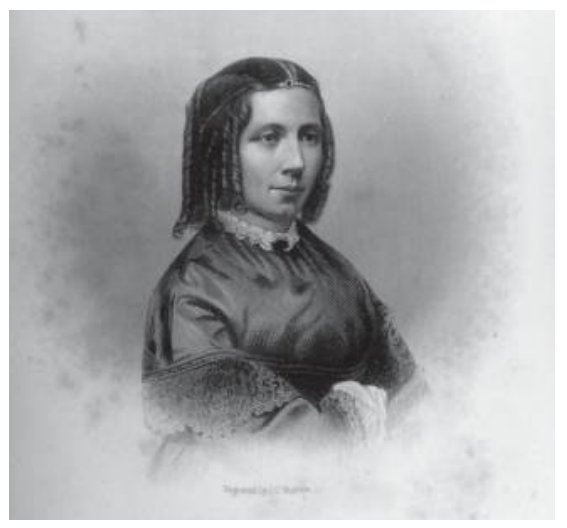

Harriet Beecher Stowe

The society's secretary, Susan F. Porter, was integral in collecting contributions by reaching out to potential authors, as well as procuring a publisher for the volume. Porter contacted the publisher of Harriet Beecher Stowe's Uncle Tom's Cabin, John P. Jewett \& Co., about publishing their upcoming book, tentatively titled The Anti-Slavery Autograph. Stowe sent a deluge of suggestions to Porter, including possible contributors, and recommended that the proposed title be changed due to the overuse and desensitization of the word "anti-slavery":

I remember at one time, that we had "antislavery," every thing even down to antislavery holders. ... The term thus became rather hacknied-one wants in this changing world something less in form, occasionally if not in fact-Suppose that we have Liberty Autographs - or "Autographs for Freedom."... .10

Stowe's crucial role in assisting in the assemblage of Autographs illuminates the effort to reach and influence the broad readership that Stowe's recent Uncle Tom's Cabin had sensitized to the slavery issue. While some abolitionists, especially in the African American community, had excoriated Stowe's support for colonization, a movement to encourage African Americans to move to the former American colony, Liberia, in West Africa, Douglass had reached out to the novelist and encouraged her to reassess her attitudes regarding colonization and African Americans. ${ }^{11}$

\section{ANTI-SLAVERY POLITICAL ENGAGEMENTS}

Autographs for Freedom was conceptualized by Douglass and Griffiths at a crucial juncture in the abolitionist movement in the United States. Political events in the immediately preceding years engendered hope that the antislavery campaign 
could reach a much broader constituency than ever before. The War with Mexico and the resultant acquisition of a huge amount of additional territory for the United States had fanned northerners' suspicion about southerners' desires to spread slavery westward. A majority of political abolitionists in the Liberty Party had merged with bolters from the Democratic and Whig parties in 1848 to create a new "Free Soil" coalition that attracted over a quarter million votes in that presidential election on a platform opposing the "extension" of slavery. Although the Free Soilers had refrained from calling for emancipation in the existing slave states, or for equal rights for African Americans, Douglass had reported positively on this new political movement in his North Star. Still a loyal Garrisonian, he had himself refrained from voting under a Constitution branded proslavery, but his editorials encouraged abolitionists without such strict scruples to cast their ballot for the Free Soilers. ${ }^{12}$

In 1850 Congress had seemingly settled the "territorial question" through a complex sectional compromise, and northern Free Soil support waned somewhat in the next few years. Resentment over the portion of the Compromise of 1850 providing for a stringent Fugitive Slave Law to compel northern cooperation in the capture and return of runaways, however, kept alive enough anti-southern sentiment to encourage further political efforts by slavery's opponents. Thousands, including Douglass and Griffiths, worked secretly in the Underground Railroad to aid fugitives from slavery to reach safe havens. The highly publicized rendition of a small number of such fugitives by authorities further dramatized for antislavery northerners the federal government's support for slaveholders' interests. ${ }^{13}$

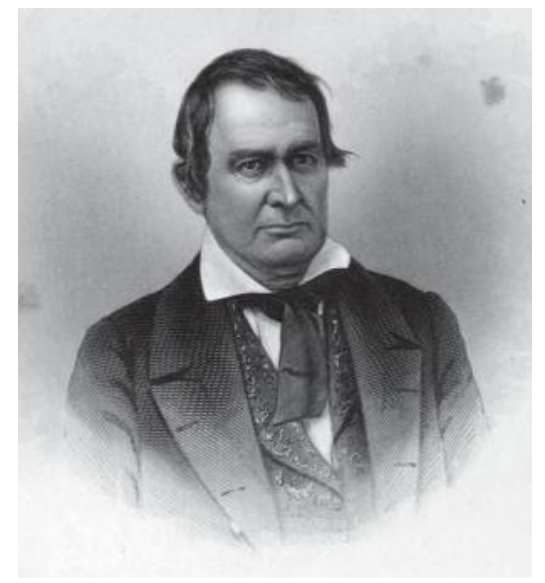

Gerrit Smith 
In this unsettled era, Douglass recounted his growing estrangement from the Garrisonians' pacifist tactics, as well as his newspaper's financial problems, in a series of private letters to New York political abolitionist Gerrit Smith, leader of a small rump of the Liberty Party that had refused to merge with more moderate antislavery northerners to form the Free Soil Party in 1848. Determined lobbying of Douglass by Smith helped persuade Douglass to shift his position on the relationship of slavery to the U.S. Constitution and thereby justify active engagement in the political process. The wealthy Smith's financial backing then allowed Douglass and Griffiths to revamp their journalistic operations in 1851, retitled the Frederick Douglass' Paper, and adopt political positions that drove off most of his Garrisonian readership. ${ }^{14}$ Douglass and Smith, with Griffiths often acting as intermediary, editorially attempted to reinvigorate political abolitionism by seeking common ground with Free Soilers and moderately antislavery Whigs. ${ }^{15}$

By early 1852, when the idea for assembling and publishing Autographs for Freedom was first conceived, the failure of Smith's strategy in reviving the political power of the Liberty Party became apparent not just to Douglass and Griffiths, but even Smith himself. During the year, as Griffiths, with the help of Stowe and Porter, assembled the Autographs, Douglass cooperated closely with Smith in an unsuccessful effort to bring the Free Soiler coalition to more enlightened positions on issues of emancipation and racial equality. Douglass had initially endorsed the Free Soil/Democratic ticket of John P. Hale and George W. Julian in hopes that the candidates would take antislavery positions in advance of their party. ${ }^{16}$ When this strategy failed, Smith and most of his followers reluctantly nominated William Goodell, another Autographs contributor, as the Liberty Party's presidential nominee. Douglass broke with Smith and continued to campaign for Hale and Julian in both speeches and editorials. In that year, Smith moved into an electoral alliance with more moderate reformers around his central New York hometown in Peterboro and ran for a seat as an "independent" in the U.S. House of Representatives. Douglass devoted most of October 1852 to traveling Smith's district, speaking on behalf of his election. While the Hale-Julian ticket failed to carry a single state in the presidential balloting, Smith surprised predictions by winning election to Congress by a plurality in a three-way election. ${ }^{17}$

\section{FORGING THE ABOLITIONIST COALITION}

The selection of authors recruited for Autographs for Freedom and the contents of their contributions reveal a great deal about the calculated pragmatic coalition-building approach Douglass and Griffiths, with Smith's implicit backing, had adopted by 1852 . The recruitment of a number of prominent Free Soilers such as Charles Sumner and Horace Mann, and moderate antislavery Whigs such as 
William H. Seward, indicated the pair's desire for Autographs to have a wider impact guiding northern antislavery perspectives. By working together with these "moderates" in projects like Autographs, political abolitionists like Douglass and Smith could hope to move the moderates in the direction of their more stringent antislavery positions.

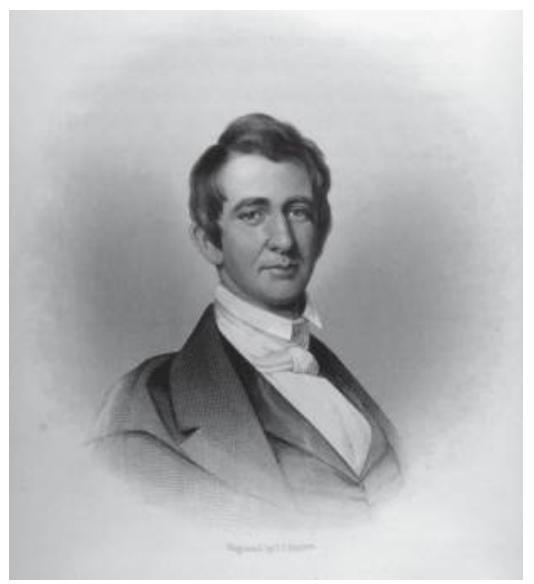

William H. Seward

Conversely the two most prominent political abolitionists, Smith and Goodell, wrote Autographs essays on religious rather than political themes. By avoiding raising potentially divisive issues such as the contention that the U.S. Constitution was fundamentally antislavery and therefore the federal government already possessed power to enact an emancipationist measure, which both men frequently proclaimed elsewhere, the two assisted the effort of Autographs to emphasize broad areas of consensus among non-Garrisonian antislavery factions.

Autographs also underlined Douglass's complete break from the Garrisonians. In May 1852 the Garrisonians' American Anti-Slavery Society held its annual meeting in Rochester. This gathering featured a special session devoted exclusively to condemning Douglass for his apostasy. As Autographs was then in its planning stage, it was no surprise that with the exception of Samuel J. May, himself a renegade on the issues of politics and violent tactics, no Garrisonian was represented in the volume's large assemblage of antislavery writers. Instead, Autograph's essays endorsed voting, which Garrisonians opposed as sanctioning the nation's proslavery government, and treated the northern churches as potential antislavery allies, instead of the "bulwark of slavery" that the Garrisonians claimed. The essay entitled "Why Slavery is in the Constitution" by James G. Birney, seemingly concedes the Garrisonian view of the U.S. Constitution as a 
proslavery document, although he also asserted that most framers believed that on account of the principles of the Declaration of Independence and "the feeling of justice pervading all classes of persons, and to the progress of refinement and true civilization, slavery would ultimately disappear." This equivocation caused Julia Griffiths to insert her own editorial declaration at the end of Birney's article: "The Constitution of the United States authorizes no man to hold another as a slave."18 The selection of British abolitionist Joseph Sturge, who had vociferously condemned Garrison for his anticlericalism, further illustrates Douglass's new independence. Sturge's letter in Autographs offers a religious defense of abolitionism, arguing that no divine blessings will be bestowed upon the Americans' cause until the scourge of slavery is abolished. ${ }^{19}$

A notable divergence that Autographs for Freedom made from Garrisonian ideology was the volume's total silence on the divisive question of women's rights. Douglass, of course, has been long remembered for his attendance at the 1848 Seneca Falls and other very early women's rights conventions. Gerrit Smith also held advanced views of the subject for the time. Ironically, it was Julia Griffiths of the three who refrained from endorsing such controversial positions as woman suffrage or dress reform. Instead, she preferred what she labeled "practical feminism," where women participated actively in moral reform causes, but refrained from asserting their equality with males. While women were well represented among Autographs' authors, their views generally fell closer to Griffiths's than to the feminism championed by most Garrisonians. Eschewing women's rights as a topic in Autographs seems in accord with its strategy of stressing common ground between political abolitionists and more moderate northerners to forge a wider abolitionist coalition. ${ }^{20}$

If there was a risk in this stance of offending women, Autographs helped evade it by the prominent place the gift book gave to its most famous contributor, Harriet Beecher Stowe. Although publication of her internationally best-selling Uncle Tom's Cabin was only a year passed, Stowe was already the nation's most celebrated woman-of-letters. ${ }^{21}$ Stowe contributed a poem, a short story, and a letter from the Earl of Carlisle, George William Frederick Howard, for inclusion in the volume. The poem, "Caste and Christ," is a religious condemnation of slavery, where Christ declares, "He who scorns his lowliest brother,/Never shall have hand of mine." ${ }^{22}$ Literary scholar Robert S. Levine writes that this piece was a response to Stowe's critics of Uncle Tom's Cabin, such as black nationalist Martin Robison Delany who rebuked Stowe's portrayal of black passivity. ${ }^{23}$ Stowe's short story "The Two Altars; or Two Pictures in One," written prior to Uncle Tom's Cabin, was an overt attack on the Fugitive Slave Law. Advertisements for Autographs list Stowe first among the volume's contributors. ${ }^{24}$ It seems safe to infer that Griffiths's and Douglass's strategy was to use Stowe's celebrity to attract many 
more readers to Autographs, not only to increase the revenue it produced but to get their version of abolitionist ideology into as many homes as possible. ${ }^{25}$

Another example of the underlying coalition-building strategy Griffiths and Douglass pursued in their selection of contributors was the recruitment of Catherine Beecher and Charles G. Finney, who both had consciously distanced themselves from abolitionist societies despite having strong antislavery principles. Catherine Beecher, sister of Harriett, focused her attentions on female education and women's roles in society, remaining outside of abolitionist and political circles. Finney, Presbyterian minister, educator, and an influential leader of the Second Great Awakening, spent much of the 1850s traveling both stateside and abroad evangelizing. While both were antislavery, their efforts focused on religious, moral, and educational aspects of social reform. ${ }^{26}$ Their presence as authors, along with the essays by Smith and Goodell, demonstrated the firm belief that churches as moral institutions should help guide the antislavery campaign. As much as the political essays, these religiously-oriented contributions set the abolitionism espoused in Autographs well-apart from the outspokenly anticlerical position of the Garrisonians.

Another goal that Douglass and Griffiths pursued for Autographs was securing Douglass's position of leadership of the small northern free black community. Douglass's principal rival in the early 1850s was Martin Delany, a former associate editor of the North Star and an early proponent of African American emigration to Africa. The focus of their disagreements centered on advocacy of emigration to Africa or some other less racist environment. The debate displayed very different attitudes regarding whether northern whites would ever treat Africans as equals, with Douglass remaining more hopeful than Delany. The dispute intensified when the two leaders diverged sharply in their appraisal of Harriet Beecher Stowe's recently published bestseller Uncle Tom's Cabin. Delany denounced Stowe's racial condescension and endorsement of colonization while Douglass recognized Uncle Tom's Cabin as a flawed, but still very useful antislavery tool. Robert Levine has argued that The Heroic Slave was composed as a "proleptic response" to the ideological attack that Martin Delany and pro-emigrationist African Americans would launch on Harriet Beecher Stowe. ${ }^{27}$

The contributor list to Autographs revealed that Douglass and Griffiths chose to combat the challenge from the emigrationist movement by denying it publicity in the gift book, just as Douglass largely ignored its meetings and pamphlets in his newspaper. Several regular black contributors to the Frederick Douglass' Paper, such as James McCune Smith and William G. Allen, wrote pieces for Autographs, but neither Delany, nor any black writer known to favor the emigration plans, was included in the collection. ${ }^{28}$ Black poet James Monroe Whitfield from Buffalo, who later aligned with Delany in the debate over emigration, did write for 
Autographs, but his poem "How Long," despite a reference to "Gambia," seems to advocate antislavery issues other than emigration. Douglass and Griffiths might have been attempting to win Whitfield away from the Delany camp, as well as displaying African American literary talents, by publishing one of Whitfield's poems in the gift book. ${ }^{29}$

\section{BEYOND EDUCATION AND MORAL SUASION}

Frederick Douglass and presumably Julia Griffiths had one other goal to pursue in assembling and publishing Autographs for Freedom: persuading northern opponents of slavery that employing violent tactics might be the only effective way to achieve emancipation. The older historical portrayal of most abolitionists as committed pacifists has been effectively challenged by scholars such as Merton L. Dillon, Stanley Harrold, Peter Hinks, and others in recent decades..$^{30}$ Certainly Quakers and fervent evangelicals such as Lewis Tappan had embraced nonviolent principles at the start of organized abolitionism in the early 1830s. By the end of that decade, perfectionist followers of William Lloyd Garrison had adopted the "non-resistant" ideology that renounced involvement in any form of coercion, including government. At the same time, however, many other abolitionists had sanctioned and even engaged in defensive violence against the assaults from proslavery mobs. More and more abolitionists also defended violent resistance to slave renditions, especially following passage in 1850 of the Fugitive Slave Law. Therefore, it is fair to characterize abolitionist attitudes in the early 1850 s toward violent antislavery strategies as ambivalent and open to persuasion by the contributions to Autographs. ${ }^{31}$

The strategy of converting readers to acceptance of violent antislavery tactics seems apparent in Griffiths's layout of the book's contents. While earlier entries seem to uphold the traditional abolitionist disinclination toward violent means, the volume builds to a concluding crescendo of four works, including Douglass's The Heroic Slave, which advocate a more radical, violently aggressive strategy. ${ }^{32}$ Inspired by the true story of the 1841 revolt led by Madison Washington aboard the slave ship Creole, Douglass's novella is a fictional recounting of those dramatic events. The novella has two distinct narrative voices, that of Madison Washington and a white northerner named Mr. Listwell. In Part I, Mr. Listwell overhears Washington's soliloquy regarding his life as a slave and his determination to escape. Listwell is so moved by the speech that it "rung through the chambers of his soul, and vibrated through his entire frame," vowing to himself to "atone for my past indifference to this ill-starred race, by making such exertions as I shall be able to do, for the speedy emancipation of every slave in the land." 33 Douglass brilliantly uses aggressive rhetoric throughout the novel and equally maintains the emphasis on the relationship between Washington and Listwell to 
incite northern white abolitionists to action. Further, Listwell gives white readers someone to identify with, and by witnessing Listwell's transformation into an abolitionist, Douglass hopes that his white readers, many newly sensitized to the slavery issue by Uncle Tom's Cabin, will undergo the same transformation. ${ }^{34}$

Within the text, Douglass only mentions two contemporary abolitionists, Garrison and Smith. The pacifist Garrison receives short shrift, while Douglass ensures his readers that Gerrit Smith was "a devoted friend" to African Americans and would accept Madison Washington "gladly." 35 Although Douglass maintained a focus on the relationship between a white abolitionist and his black protagonist, The Heroic Slave further attempted to solidify Washington as a heroic exemplar representing black manhood. Literary scholar Richard Yarborough concluded, "As Douglass knew from personal experience, revolution usually entails violence, and black self-assertion in the face of racist attempts at dehumanization often necessitates a direct and forceful assault upon the very structures of social power that provide most whites (especially white males) with a sense of self-worth, security, and potency." ${ }^{36}$ Douglass's decision to not dramatize the violent acts of Washington and his fellow slaves aboard the Creole attests to his over-arching goals of appealing to white readers. Nevertheless, Douglass clearly embraces violent slave rebellion as he portrays Washington as a courageous character embodying heroic African American masculinity.

The final additions endorsing anti-slavery violence came from John Thomas, John H. Raymond, and William G. Allen. An assistant editor of Frederick Douglass' Paper and active proponent of political abolitionism and land redistribution, John Thomas contributed an essay praising two mid-19th-century European revolutionaries, Hungarian Louis Kossuth and Italian Giuseppe Mazzini. Thomas likened both men to George Washington in bravely fighting against human oppression. Thomas saw the violent tactics these men employed as part of a divine plan. "When God decrees great events, he brings upon stage and qualifies human instrumentalities by which such events are accomplished. . .." ${ }^{37}$ John Raymond, a professor of belles-lettres at the then only two-year old University of Rochester, in "A Plea for Free Speech," condemned the new fugitive slave law for nationalizing slavery through its requirement that northerners cooperate in the rendition of fugitives from slavery. Raymond declared that he "will refuse to obey the law" because it was opposed to the fundamental principles of human justice, and he quoted Patrick Henry, "If this be treason, make the most of it." ${ }^{\prime 38}$

Autographs for Freedom concludes with a contribution from William G. Allen, an African American professor of Greek and German languages at the small integrated New York Central College in McGrawville. Allen's work parallels Douglass's The Heroic Slave in its endorsement of violent antislavery tactics. Allen's subject was the Cuban slave poet Juan Placido, who was executed by 
Spanish authorities for his role in an aborted uprising in 1844. Allen compares Placido to Kossuth, the Hungarian freedom fighter known for his courage to rebel against Austrian tyranny. Kossuth had recently been well received on a fund-raising tour of the United States. Allen concludes that Placido is "worthy to stand side by side with Hungary's illustrious son" and "that God hath not given to one race alone, all intellectual and moral greatness." 39

\section{SUCCESS AND THE SECOND EDITION}

It is impossible to measure the precise impact of the Autographs for Freedom on the abolitionist movement. It was sold at the Christmas season fair of the Rochester Ladies' Anti-Slavery Society, and later at Douglass's newspaper office and at bookstores in major northern cities. The publisher John P. Jewett \& Co. took out advertisements for Autographs in antislavery newspapers, including Garrison's Liberator. ${ }^{40}$ Figures on sales are not available, but they must have produced an encouraging amount of revenue because Griffiths and her society were soon planning a second edition of the gift book for 1854 .

Contents of the second edition of Autographs for Freedom, published a year after the first, revealed that Douglass and Griffiths still strove to appeal to a broad coalition of political and religious abolitionists and more moderate antislavery northerners. Liberty Party figures Gerrit Smith and William Goodell both wrote for the second edition, as did Free Soilers Charles Francis Adams, Joshua R. Giddings, and Cassius M. Clay, and antislavery Whigs Horace Greeley and William H. Seward. At least a dozen of the nearly fifty contributors were ordained ministers, which enhanced the gift book's appeal to the religious community. The number of female contributors also increased to nine. Harriet Beecher Stowe wrote for the gift book again, along with her brother, the popular Congregational minister Henry Ward Beecher. Eight African Americans, several of whom were regular contributors to Douglass's newspaper, wrote for the second edition of Autographs. Once again, only a single abolitionist associated with the Garrisonians, Boston lawyer Samuel E. Sewell, could be found among the authors. The second edition of Autographs had a new publisher willing to add more graphics to the volume.

Wanzer, Beardsley and Company of Rochester improved the binding and printing and added portraits of contributors to attract new buyers. ${ }^{41}$ As had its predecessor, the 1854 Autographs for Freedom accentuated cultural as well as political and religious connections among its readers to foster more cooperation in antislavery efforts.

The aspirations of Douglass and Griffiths for Autographs for Freedom were heavily shaped by the political climate of the early $1850 \mathrm{~s}$, featuring growing 
northern resentment against the Fugitive Slave Law and the unprecedented popularity of Harriet Beecher Stowe's Uncle Tom's Cabin. Douglass, Griffiths, and their abolitionist allies believed it possible to guide moderate antislavery northerners in religious and especially political circles to higher antislavery ground. One unanticipated consequence of the passage of the inflammatory Kansas-Nebraska Act in 1854, however, was its disruptive impact on these hopes for a new antislavery coalition. The threatened spread of slavery onto the prairie territories, where it had been prohibited by the Missouri Compromise of 1820 , revived the popularity of an anti-extensionist movement across the North. The small cadre of Free Soil/Democratic politicians seized the opportunity to unite with northern Whigs and Democrats emboldened to resist this "Slave Power" aggression. This new alliance that ultimately became the Republican Party, however, displayed even less interest in emancipation in the existing slave states, or the protection of African American civil rights, than had its Free Soil predecessor. Frustrated at his ineffectuality in Congress in advancing abolitionism, Gerrit Smith resigned his House seat and with his small circle of followers launched the Radical Abolition Party to offer northern voters an uncompromising antislavery alternative to the Republicans. Radical abolitionists would champion full racial equality and the belief that the Constitution permitted the federal government to abolish slavery. ${ }^{42}$ The diverging moderate and radical political opponents of slavery would not again achieve the level of cooperation that had been reached between 1852 and 1854 until the outbreak of the Civil War in 1861.

Usually dismissed by earlier researchers as a simple fundraising vehicle assembled by Julia Griffiths to assist Douglass's struggling journalistic enterprises, Autographs for Freedom instead was an important effort by the two abolitionists to influence the direction of those rapidly shifting antislavery currents. ${ }^{43}$ The volume certainly appears to have been an effort by the pair to rally support in ongoing ideological battles with both Garrisonian abolitionists and advocates of African American emigrationism. A close inspection of the volume's publication history, from conception through sales and an analysis of its authors and the content of their contributions, also exposes a complex and ambitious political agenda that Douglass, Griffiths, and their small circle of central New York supporters devised for reshaping the strategies of non-Garrisonian abolitionism. The contemplated political alliance envisioned in Autographs, between Smith's circle and northern antislavery moderates, ultimately foundered just a few years after the gift book's publication with the formation of the anti-extensionist Republican Party competing with Radical Abolition Party in $1854 .{ }^{44}$ Douglass would shift his support back and forth between the two camps for a time, but ultimately he abandoned hope that the moderates would ever champion racial justice. This break with the more moderate Republicans would free Douglass, Smith, and other radical politi- 
cal abolitionists to put their faith in John Brown in employing the same type of violent antislavery tactics defended by Douglass in The Heroic Slave and several other authors in the pages of Autographs for Freedom.

One other important conclusion to draw from examining this collaborative effort between Douglass and Griffiths illuminates how skillfully she employed her editorial talents to support Douglass's new political activism outside of the Garrisonian orbit. Griffiths's thoughtful design of Autographs, from moderate to more radical contributions, illustrates her understanding of the evolving abolitionist ideologies and their reception among readers..$^{45}$ Griffiths's editorial decision to place contributions advocating antislavery violence, including Douglass's The Heroic Slave, at the volume's conclusion where they could make a lasting impression upon the reader was intended to persuade northerners to consider more belligerent action against slavery. After dismissing Garrisonian non-resistance and Delaney's emigrationist visions, giving political and religious antislavery tactics a final try, Autographs for Freedom symbolically presents violent abolitionism as the last resort.

\section{NOTES}

${ }^{1}$ For scholarly works discussing the use of anti-slavery violence in The Heroic Slave, see Krista Walter, "Trappings of Nationalism in Frederick Douglass's The Heroic Slave," African American Review 34, no. 2 (2000): 233-47; Ellen Weinauer, "Writing Revolt in the Wake of Nat Turner: Frederick Douglass and the Construction of Black Domesticity in 'the Heroic Slave,' "Studies in American Fiction 33, no. 2 (2005): 193-202; and Richard Yarbrough "Race, Violence, and Manhood: The Masculine Ideal in Frederick Douglass's 'The Heroic Slave," Frederick Douglass: New Literary and Historical Essays, ed. Eric Sundquist (Cambridge, MA, 1990): 166-88.

${ }^{2}$ Philip S. Foner, The Life and Writings of Frederick Douglass, Early Years, 1817-1849 (New York, 1950$), 72$.

${ }^{3}$ William S. McFeely, Frederick Douglass (New York, 1991), 146-49; Tyrone Tillery, "The Inevitability of the Douglass-Garrison Conflict," Phylon 37 (January 1976): 137-45, 149.

${ }^{4}$ David Blight, Frederick Douglass' Civil War: Keeping Faith in Jubilee (Baton Rouge, LA, 1989), 28-30; L. Diane Barnes, Frederick Douglass: Reformer and Statesman (New York, 2013), 62-66, 75; McFeely, Frederick Douglass, 156-57.

${ }^{5}$ Frederick Douglass to Julia Griffiths, 28 April 1848, in The Frederick Douglass Papers, Series 3: Correspondence, Vol. 1, ed. John R. McKivigan (New Haven, CT, 2009), 302-303.

${ }^{6} \mathrm{~A}$ low point in this campaign of character assassination against Douglass came in an editorial in Garrison's Liberator: "For several years past, he [Douglass] has had one of the worst advisers in his printing-office, whose influence over him has not only caused much unhappiness in his own household, but perniciously biased his own judgment; who, active, facile, mischievous, has never had any sympathy with the American Anti-Slavery Society, but would doubtless rejoice to see it become extinct; and whose sectarianism is manifestly paramount to any regard for the integrity of the anti-slavery movement." William L. Garrison, "Editorial," Liberator (Boston, MA), 18 November 1853.

${ }^{7}$ Nancy A. Hewitt, Women's Activism and Social Change: Rochester, New York, $1822-1872$ (Ithaca, NY, 1984), 151, 234-35.

${ }^{8}$ Meaghan M. Fritz and Frank E. Fee, Jr., "To Give the Gift of Freedom: Gift Books and the War on Slavery," American Periodicals: A Journal of History, Criticism, and Bibliography 23, no. 1 (2013): 61-62; Ralph Thompson, American Literary Annuals \& Gift Books (New York, 1936); Ralph Thompson, "The Liberty Bell and Other Anti-Slavery gift books," New England Quarterly 7 (March 1934): 154-78. 
${ }^{9}$ The Rochester Ladies' Anti-Slavery Society adopted the following resolution defining their position: "It is proper to state, coming into existence at this late day, and finding anti-slavery men and women much divided in opinion, in respect to their different organizations, this association did not deem it duty to make an election between old and new organization. 'Liberty Party,' or 'Free Soil,' but preferred to assume an independent position, with a view to co-operate with all those whose love for the anti-slavery cause rises superior to their connection with any particular party or sect of abolitionists. We feel that there are too many points of agreement among the friends of the slave, and that the points of difference are too small to justify contention and strife between them." "The First Report of the Rochester Ladies' Anti-Slavery Sewing Society," Frederick Douglass' Paper, 1 April 1852.

${ }^{10}$ Harriet Beecher Stowe to Susan F. Porter, 20 June 1852, Porter Family Papers, Rare Books, Special Collections and Preservation, Rush Rhees Library, University of Rochester, Rochester, New York.

${ }^{11}$ Robert S. Levine, Martin Delany, Frederick Douglass, and the Politics of Representative Identity (Chapel Hill, NC, 1997), 16, 60-61, 71-76.

${ }^{12}$ Frederick J. Blue, The Free Soilers: Third Party Politics, 1848-1854 (Urbana, IL, 1973), 7-12, 14, 197; Richard H. Sewell, Ballots for Freedom: Antislavery Politics in the United States, 1837-1860 (New York, 1976), 117-21; Lawrence J. Friedman, Gregarious Saints: Self and Community in American Abolitionism, 1830-1870 (Cambridge, MA, 1982), 117-19, 189.

${ }^{13}$ Barnes, Frederick Douglass, 66, 72; McFeely, Douglass, 167, 172-73; Erwin Palmer, "A Partnership in the Abolition Movement," University of Rochester Library Bulletin 26, 1, 2 (Autumn-Winter 1971-72): 1-19.

${ }^{14}$ Douglass merged his paper with an even smaller weekly, the Liberty Party Paper, edited by John L. Thomas. Smith had subsidized the latter and now pledged funds to sustain the new combined sheet. Douglass to Gerrit Smith, 30 March 1849, 21 January 1851, Frederick Douglass Papers, 3:375-78, 438-54; Barnes, Douglass, 74-75; John Stauffer, Black Hearts of Men: Radical Abolitionists and the Transformation of Race (Cambridge, MA, 2002), 166-67.

${ }^{15}$ McFeely, Douglass, 167; Barnes, Frederick Douglass, 74-75.

16“'Our Position in the Present Presidential Canvass," Frederick Douglass' Paper, 10 September 1852; Quarles, Douglass, 147-52.

${ }^{17}$ Blight, Frederick Douglass' Civil War, 34-37; Blue, Free Soilers, 255-56, 261; Benjamin Quarles, Frederick Douglass (Washington, DC, 1948), 151-52.

${ }^{18}$ Autographs for Freedom, vol. 1, ed. Julia Griffiths (Boston, MA, 1853), 125.

${ }^{19}$ Ibid., 19.

${ }^{20}$ Frank E. Fee, Jr., “To No One More Indebted: Frederick Douglass and Julia Griffiths, 1849-1863,” Journalism History 37, No. 1 (2011): 18, 21. Stauffer, Black Hearts of Men, 106, 208-09, 212; Barnes, Douglass, 69; Quarles, Douglass, 132-33.

${ }^{21}$ First published serially in the antislavery Washington, DC, newspaper, the National Era, Uncle Tom's Cabin was published by the Boston firm of John P. Jewett on 20 March 1852. It sold 10,000 copies its first week in print and more than 300,000 in its first year. Joan D. Hedrick, Harriet Beecher Stowe: A Life (New York, 1994), 208, 223.

${ }^{22}$ Autographs for Freedom, 6.

${ }^{23}$ Levine, Martin Delany, 69, 164-165, 174-178, 193.

24“"Autographs for Freedom,” Frederick Douglass'Paper, 21 January 1853.

${ }^{25}$ In a similar fashion, many of the British authors recruited for the volume, including Joseph Sturge, George W. F. Howard, Samuel Wilberforce, and Wilson Armistead, were used to advance the gift book's European sales.

${ }^{26}$ Kathryn Kish Sklar, Catharine Beecher: A Study in American Domesticity (New Haven, CT, 1973), xii-xiv, 19 , 132; James David Essig, “The Lord's Free Man: Charles G. Finney and His Abolitionism," Civil War History 24 (March 1978): 25-45.

${ }^{27}$ Levine, Martin Delany, 82-84.

${ }^{28}$ Ibid., 70, 97-98.

${ }^{29}$ Robert S. Levine and Ivy G. Wilson, eds., The Works of James M. Whitfield (Chapel Hill, NC, 2011), 8-10.

${ }^{30}$ Encyclopedia of Abolition and Antislavery, 2:723-31.

${ }^{31}$ Ibid.

${ }^{32}$ At least one other contribution to Autograph for Freedom seems to defend violent antislavery tactics. "The Slave and the Slave-Owner" by Catharine Maria Sedgewick offers compelling language that could be a subtle endorsement of anti-slavery violent tactics. She writes that she would rather be a slave than a slave-owner, because owners "smell the battle afar off" and "fearful, threatenings of the gathering storm," but the enslaved is 
hopeful and "looks forward with ever-growing hope to the struggle that must come." Autographs for Freedom, 24-26.

${ }^{33}$ Frederick Douglass, The Heroic Slave: A Cultural and Critical Edition, eds. Robert S. Levine, John Stauffer, and John R. McKivigan, (New Haven, CT, 2015), 8-9.

${ }^{34}$ Yarborough, "Race, Violence, and Manhood," 176-188.

${ }^{35}$ Douglass, Heroic Slave: A Cultural and Critical Edition, 18-19.

${ }^{36}$ Yarborough, "Race, Violence, and Manhood," 181.

${ }^{37}$ Thomas defended Kossuth from the charge of some other abolitionists that the Hungarian had remained silent on the slavery issue during a recent tour of the United States to avoid a negative response to his fund raising for his own cause. Autographs for Freedom, 172.

${ }^{38}$ Ibid., 250, 254.

${ }^{39}$ Autographs for Freedom, 262.

${ }^{40} \mathrm{Fee}$, "To No one More Indebted," 16; Fritz and Fee, "To Give the Gift of Freedom," 73.

${ }^{41}$ Fritz and Fee, "To Give the Gift of Freedom," 67-68, 74.

${ }^{42}$ Stauffer, Black Hearts of Men, 12-13, 18-19.

${ }^{43}$ Douglass biographer William McFeely labels Autographs an "excellent scheme" to raise money for Douglass's newspaper; an appraisal echoed by Robert Levine, Diane Barnes, and others. For example, see the assessment of Ralph Thompson in American Literary Annuals \& Gift Books, 5, and "Liberty Bell and Other Anti-Slavery gift books," $155,158,160-63$, which minimize the effectiveness of gift books in general as propaganda tools. McFeely, Douglass, 173-74; Levine, Martin Delany, 149, 261; Barnes, Frederick Douglass, 77; Palmer, "Partnership in the Abolition Movement," 6-8.

${ }^{44}$ Griffiths's return to Great Britain in summer 1855 greatly contributed to the slow decline in the financial state of Douglass's newspaper. Fee, "To No One More Indebted," 20-21.

${ }^{45}$ Autographs for Freedom was also a fundraising venture and Griffiths calculated carefully in placing entries that promote antislavery violence in the volume's end where a potential purchaser might not take note of them. 